\title{
Hexavalent Chromium Reduction by Immobilized Cells of Bacillus sphaericus AND 303
}

\author{
Arundhati Pal ${ }^{1}$, Sudeshna Datta ${ }^{2}$ and Amal K. Paul ${ }^{2 *}$ \\ ${ }^{1}$ Department of Botany; Serampore College, 9; William Carey Road; Serampore, Hooghly 712201 - India \\ ${ }^{2}$ Microbiology Laboratory; Department of Botany; University of Calcutta; 35, Ballygunge Circular Road; \\ Kolkata 700019 - India
}

\begin{abstract}
Bacillus sphaericus AND 303, a Cr(VI)-resistant and reducing bacterium reported from serpentine outcrops of Andaman was evaluated for Cr(VI) reduction using immobilized cells under batch culture. Screening of inert matrices for entrapment of whole cells indicated that polyvinyl alchohol-alginate was the most effective one reducing $87.5 \%$ of $20 \mu \mathrm{M} \mathrm{Cr}(V I)$ in $24 \mathrm{~h}$. The rate of chromate reduction was dependent on initial $\mathrm{Cr}(\mathrm{VI})$ and biomass concentrations. The PVA cell beads were recycled three times without cell leakage and disintegration. The reduction efficiency was improved in the presence of glucose and glycerol as electron donors leading to complete reduction. However, the presence of additional metal ions was inhibitory to $\mathrm{Cr}(\mathrm{VI})$ reduction. It could be emphasized that PVA-alginate immobilized cells of B. sphaericus AND 303 could be used as a continuous bioprocess in treating Cr(VI) contaminated effluents.
\end{abstract}

Key words: Bacillus sphaericus; Immobilized cells; PVA alginate; $\mathrm{Cr}(\mathrm{VI})$ reduction: Bioremediation

\section{INTRODUCTION}

Chromium, an essential micronutrient, has widespread industrial applications in leather tanning, dye and paints, electroplating and metallurgy. The present pattern of industrial activities often discharge chromium laden waste effluents into the environment without proper treatment and leads to severe environmental pollution. Because of their non-biodegradable nature, heavy metals accumulate in the environment and in food chains and disrupt the biological processes. Although $\mathrm{Cr}$ can exist in different oxidation states, the hexavalent form $[\mathrm{Cr}(\mathrm{VI})]$ is highly toxic, considered mutagenic and carcinogenic as it is soluble at neutrality and easily penetrate biological membranes impairing cellular structure and functions. On the contrary, trivalent chromium [ $\mathrm{Cr}(\mathrm{III})]$ is less harmful as it is insoluble at $\mathrm{pH} 7.0$ and impermeable to cell membranes. Biotransformation of $\mathrm{Cr}(\mathrm{VI})$ to $\mathrm{Cr}$ (III) is an environment-friendly option of $\mathrm{Cr}$ detoxification (Ohtake and Silver 1994). Reduction of chromate by a wide variety of $\mathrm{Cr}$ resistant Gram-positive and Gram-negative heterotrophic and photoautotrophic bacteria as well as different species of yeast and fungi have been reported and appeared to be the most promising candidates for bioremediation (Cervantes et al. 2001). Reduction of $\mathrm{Cr}(\mathrm{VI})$ by microbial enzymes reduces toxicity and environmental mobility where $\mathrm{Cr}(\mathrm{III})$ precipitates as insoluble $\mathrm{Cr}(\mathrm{OH})_{3}$ at neutral $\mathrm{pH}$ and aids in physical removal by centrifugation (Wang 2000). Growing bacterial cells as well as their cell-free extracts reduced $\mathrm{Cr}(\mathrm{VI})$ under aerobic or anaerobic

*Author for correspondence: amalk_paul@yahoo.co.in 
condition or both. While aerobic chromate reduction by bacteria is associated with soluble cellular proteins utilizing endogenous electron reserves or NADH as the electron donor (Park et al. 2000; Pal et al. 2005), anaerobic reduction is membrane bound where $\mathrm{Cr}(\mathrm{VI})$ serves as the terminal electron acceptor through respiratory chains involving cytochromes (Ohtake et al. 1990; Shen and Wang 1994). Bacterial cells and enzymes immobilized in different polymer matrices such as agar-agar, agarose, polyacrylamide, calcium alginate, diatomite, polyvinyl alcohol, etc. have been used for $\mathrm{Cr}$ reduction and proved to be effective. These immobilized cells being more stable, can be reused and are easy to regenerate with easier solid-liquid separation (Humphries et al. 2005; Elangovan et al. 2010). Under immobilized conditions, cells are protected against the excessive toxic action of high chromate concentration and thereby improve the cellular activities compared with free cells. $\mathrm{Cr}(\mathrm{VI})$ reduction by the immobilized cells have been used in different systems such as packed bed biofilm reactor, membrane bioreactor or column bioreactors operating under batch, continuous or stirred mode (Tucker et al.1998; Pattanapipitpaisal et al. 2001; Cordoba et al. 2008).

In our previous study, we have reported a $\mathrm{Cr}(\mathrm{VI})$ resistant and reducing bacterium, Bacillus sphaericus AND 303 (MTCC 6512) from serpentine outcrops of Andaman, India and have also enumerated chromate reduction studies during the growth, with viable free whole cells and using cell-free extracts (Pal and Paul 2004; Pal et al. 2005). The present study reports on the reduction of $\mathrm{Cr}(\mathrm{VI})$ by the immobilized cells of $B$. sphaericus AND 303 and influence of environmental conditions on chromate reduction.

\section{MATERIALS AND METHODS}

\section{Bacterial strain and culture conditions}

The $\mathrm{Cr}(\mathrm{VI})$-resistant and reducing bacterial isolate Bacillus sphaericus AND 303 (MTCC 6512) was obtained from the Microbiology Laboratory Culture Collection, Department of Botany, University of Calcutta, Kolkata and used throughout this study. The bacterium was previously isolated from serpentine outcrops of Andaman, India (Pal and Paul 2004). It was grown on slopes of Tryptic Soy Agar (Himedia, India) (containing casein hydrolysate $17.0 \mathrm{~g}$; peptic digest of soyabean $3.0 \mathrm{~g}$; $\mathrm{NaCl} 5.0 \mathrm{~g}$ and $\mathrm{K}_{2} \mathrm{HPO}_{4}$ $2.5 \mathrm{~g}$ in $1000 \mathrm{~mL}$ distilled water) at $32^{\circ} \mathrm{C}$ for $24 \mathrm{~h}$ and maintained with repeated sub-culturing at four weeks interval.

\section{Preparation of biomass for immobilization}

For the immobilization of cells, B. sphaericus AND 303 was grown in $250 \mathrm{ml}$ Erlenmeyer flask containing $50 \mathrm{ml}$ nutrient broth at $32^{\circ} \mathrm{C}$ under shaking condition $(120 \mathrm{rpm})$ till mid-log phase (18 h). Cells were harvested aseptically by centrifugation $(10,000 \mathrm{~g})$ at $4^{\circ} \mathrm{C}$ for $10 \mathrm{~min}$, washed thoroughly with sterile normal saline and re-suspended in the normal saline before being used for immobilization.

\section{Preparation of immobilized cells}

Polyvinyl alginate (PVA), polyvinyl borate (PVB), calcium alginate (CA), agarose (Sigma Aldrich) and agar-agar (Qualigens) were evaluated for biomass immobilization following the procedure as described by Pattanapipitpaisal et al. (2001) and Wu and Wisecarver (1992).

Polyvinyl alcohol $(1.0 \mathrm{~g})$ and sodium alginate $(0.16 \mathrm{~g})$ were mixed in $19 \mathrm{ml}$ of distilled water and heated $\left(60^{\circ} \mathrm{C}\right)$ for complete dissolution of PVA. The solution was sterilized and cooled prior to the addition of freshly prepared cell suspension (0.75 $\mathrm{g}$ fresh weight of biomass.). The immobilized cell beads were prepared by extruding the mixture as drops using a sterile $5 \mathrm{ml}$ pipette into $200 \mathrm{ml}$ of chilled $\mathrm{CaCl}_{2}, 2 \mathrm{H}_{2} \mathrm{O}(2 \%$ w/v) solution and kept overnight for hardening at $4^{\circ} \mathrm{C}$. For the preparation of PVA borate beads, the extrusion was performed into an immobilizing phase containing chilled saturated boric acid and $2 \%(\mathrm{w} / \mathrm{v}) \mathrm{CaCl}_{2}, 2 \mathrm{H}_{2} \mathrm{O}$.

Calcium alginate beads were prepared by mixing $0.4 \mathrm{~g}$ sodium alginate in $19 \mathrm{ml}$ distilled water, sterilized and cooled. Cells (0.75 g fresh weight) were added to the sterilized alginate solution and beads were prepared by extruding the mixture into chilled solution of $\mathrm{CaCl}_{2}, 2 \mathrm{H}_{2} \mathrm{O}(200 \mathrm{mM})$ and kept overnight at $4^{\circ} \mathrm{C}$ for hardening. Spherical gelbeads were formed without agglomeration and exhibited rubber like properties.

Agar-agar and agarose entrapment of cells was carried out following the methods of Nilsson et al. (1983) and Manolov et al. (1995). Samples (19 ml) of polymer solutions (2\% agar-agar and $4 \%$ agarose) were mixed with $0.75 \mathrm{~g}$ wet biomass at $45^{\circ} \mathrm{C}$ and extruded into an oil phase (paraffin oil). The beads were hardened by cooling the mixture 
on ice bath for $18 \mathrm{~h}$ under continuous stirring and later removed to aqueous phase.

\section{$\mathrm{Cr}(\mathrm{VI})$ reduction studies}

Cells immobilized in PVA, PVB, CA, agarose and agar-agar beads were tested for $\mathrm{Cr}(\mathrm{VI})$ reduction in batch experiments following the procedure of Humphries et al. (2005). The beads were washed three times with sterile distilled water and added aseptically to $100 \mathrm{ml}$ of Erlenmeyer flask containing $10 \mathrm{ml}$ of mineral salts broth supplemented with $20 \mu \mathrm{M} \mathrm{Cr}(\mathrm{VI})$ and $0.1 \%$ glucose as electron donor. The assay was initiated by the addition of 10 beads per flasks. Beads without cells and immobilized heat killed cells were used as control. The flasks were incubated under shaking conditions (120 rpm) at $32^{\circ} \mathrm{C}$ and samples were withdrawn at regular interval for the determination of residual $\mathrm{Cr}(\mathrm{VI})$ following diphenyl carbazide method (Snell and Snell 1959). All the experiments were performed in triplicates and results represented the mean \pm standard error.

\section{RESULTS AND DISCUSSION}

\section{$\mathrm{Cr}(\mathrm{VI})$ reduction by free and immobilized cells} Chromate reduction by B. sphaericus AND 303 as free and PVA immobilized cells were compared under batch culture. As shown in Figure 1, in case of free cells, $14.3 \mu \mathrm{M}$ of $20 \mu \mathrm{M} \mathrm{Cr}(\mathrm{VI})$ was reduced $(>70 \%)$ in $24 \mathrm{~h}$ while immobilized cells in PVA-alginate beads showed better chromate reduction efficiency (> $85 \%)$ under similar conditions. As expected, the immobilized heat killed cells could not reduce $\mathrm{Cr}(\mathrm{VI})$ throughout the experiment.

Five inert matrices, viz. PVA-alginate, Ca-alginate, PVA-borate, agarose and agar-agar were screened for the immobilization of $B$. sphaericus cells and their performance with respect to chromate reduction, bead integrity and leaching of cells from the beads were recorded. Results as shown in Table 1 revealed that PVA-alginate immoblilized cells reduced $87.5 \%$ of $20 \mu \mathrm{M} \mathrm{Cr}(\mathrm{VI})$ after $24 \mathrm{~h}$ of incubation, but complete reduction of $\mathrm{Cr}(\mathrm{VI})$ could not be achieved by $B$. sphaericus cells in any of the matrices tested. Agar-agar, agarose and PVA-borate were inefficient for the immobilization since these beads were unstable and disintegrated within 18-24 $\mathrm{h}$ of incubation. Although Ca-alginate beads retained significant $\mathrm{Cr}(\mathrm{VI})$ reduction ability, cells started leaching out after $24 \mathrm{~h}$ and beads could not be reused. PVAalginate beads was the most suitable one in terms of their integrity as well as efficiency of chromate reduction, hence were selected for subsequent studies. PVA-alginate was also proved to be effective immobilizing agent for $\mathrm{Cr}(\mathrm{VI})$ reduction by Streptomyces griseus (Poopal and Laxman 2008) and Microbacterium liquefaciens (Pattanapipitpaisal et al. 2001).

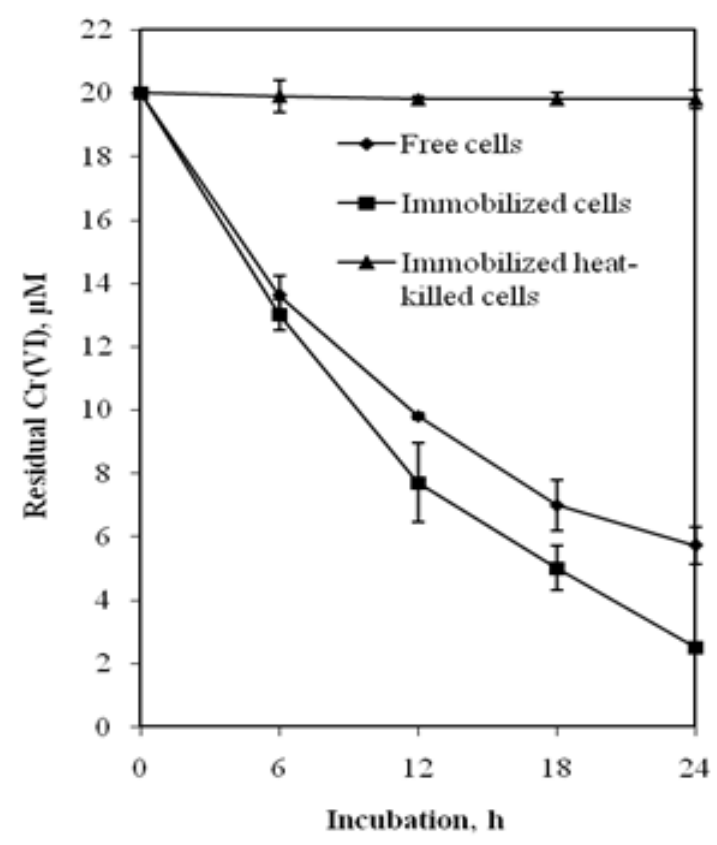

Figure 1 - Chromate reduction by free and immobilized cells of Bacillus sphaericus AND 303. 
Table 1 - Screening of various immobilizing matrices on Cr(VI) reduction by cells of Bacillus sphaericus AND 303.

\begin{tabular}{|c|c|c|c|c|c|c|}
\hline \multirow{3}{*}{$\begin{array}{l}\text { Immobilization } \\
\text { matrix }\end{array}$} & \multicolumn{4}{|c|}{$\mathrm{Cr}(\mathrm{VI}), \boldsymbol{\mu M}$} & \multirow{3}{*}{$\begin{array}{c}\operatorname{Cr}(\mathrm{VI}) \\
\text { reduction, } \\
\%(24 \mathrm{~h})\end{array}$} & \multirow{3}{*}{ Bead integrity / Cell leakage } \\
\hline & \multirow{2}{*}{$\begin{array}{c}\text { Initial } \\
(\mathbf{0} \text { h })\end{array}$} & \multicolumn{3}{|c|}{ Residual } & & \\
\hline & & $6 \mathrm{~h}$ & $18 \mathrm{~h}$ & $24 \mathrm{~h}$ & & \\
\hline PVA-alginate & 20.0 & $13.6 \pm 0.5$ & $5.0 \pm 0.7$ & $2.5 \pm 0.1$ & $87.5 \pm 7.2$ & Retained, no cell leakage \\
\hline Ca-alginate & 19.8 & $13.8 \pm 0.2$ & $8.1 \pm 0.3$ & $4.8 \pm 0.2$ & $75.0 \pm 5.0$ & Retained, cell leakage after $24 \mathrm{~h}$ \\
\hline PVA-borate & 20.0 & $14.9 \pm 0.3$ & $12.0 \pm 0.2$ & $8.1 \pm 0.2$ & $59.5 \pm 3.6$ & Partial disintegration in $24 \mathrm{~h}$ \\
\hline Agarose & 20.0 & $16.5 \pm 1.1$ & $15.2 \pm 0.1$ & $14.0 \pm 1.2$ & $30.0 \pm 5.5$ & Disintegrated in $6 \mathrm{~h}$ \\
\hline Agar-agar & 19.9 & $18.2 \pm 0.2$ & $16.8 \pm 1.5$ & $15.6 \pm 0.8$ & $21.5 \pm 2.6$ & Disintegrated within $24 \mathrm{~h}$ \\
\hline
\end{tabular}

$\mathrm{Cr}(\mathrm{VI})$ reduction was assayed in minimal salt medium. Results represent mean of triplicate experiments \pm SE.

\section{Effect of initial $\mathrm{Cr}(\mathrm{VI})$ concentration}

$\mathrm{Cr}(\mathrm{VI})$ reduction efficiency of the immobilized cells was tested over a concentration range of 10$50 \mu \mathrm{M}$ of $\mathrm{Cr}(\mathrm{VI})$. Reduction efficiency was higher with low levels of initial chromate but slowed down with increase in metal concentration (Fig 2). The PVA-alginate beads were effectively reused till $3^{\text {rd }}$ cycle with certain degree of decline in reduction efficiency after every cycle. At low $\mathrm{Cr}(\mathrm{VI})$ concentration $(10 \mu \mathrm{M})$, fresh beads reduced more than $95 \%$ chromate in $24 \mathrm{~h}$, while the reduction efficiency of the same beads declined to $62.5 \%$ during the $3^{\text {rd }}$ cycle. A visible discoloration of the medium from yellow to colorless was accompanied with significant change in color of the recycled beads from white to grey. Such changes in color of the beads was possibly due to the precipitation of reduced $\mathrm{Cr}$ (III) leading to decrease in permeability of the hexavalent chromium to cells entrapped in the matrix, thereby lowering the reduction rate. This corroborated the findings of Ganguli and Tripathi (2002) who demonstrated that low levels of chromate reduction by Pseudomonas aeruginosa A2Chr was due to the inhibitory effects of high initial $\mathrm{Cr}(\mathrm{VI})$ concentration on cellular metabolism.

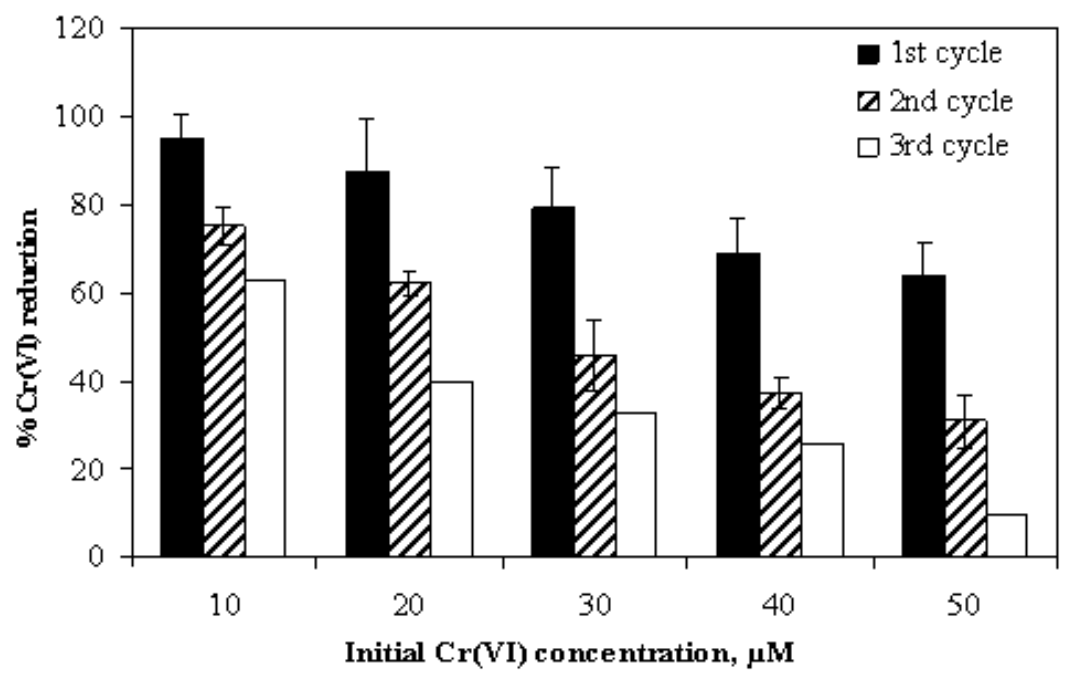

Figure 2 - Effect of chromate concentration on $\mathrm{Cr}(\mathrm{VI})$ reduction by Bacillus sphaericus AND 303 cells immobilized in PVA-alginate. $\mathrm{Cr}(\mathrm{VI})$ reduction was assayed after $24 \mathrm{~h}$ interval, cell beads were washed twice with sterile distilled water and reused for the next cycle.

\section{Effect of cell density}

Chromate reduction increased with increase in cell concentration in the PVA-alginate matrix (Fig 3). Complete reduction of initial $20 \mu \mathrm{M} \mathrm{Cr}$ (VI) was achieved in $24 \mathrm{~h}$ with a cell density of $10^{10}$ cells $/ \mathrm{ml}$. On the contrary, 90 and $60 \%$ reduction was accomplished at cell concentrations of $10^{9}$ and $10^{8}$ cells $/ \mathrm{ml}$, respectively after $24 \mathrm{~h}$ incubation. This general trend of enhanced chromate reduction with increase in cell density in the matrices was 
evident with the cells of $B$. coagulans (Philip et al. 1999) and Microbacterium sp. (Humphries et al.
2005) immobilized in polyacrylamide and PVA alginate respectively.

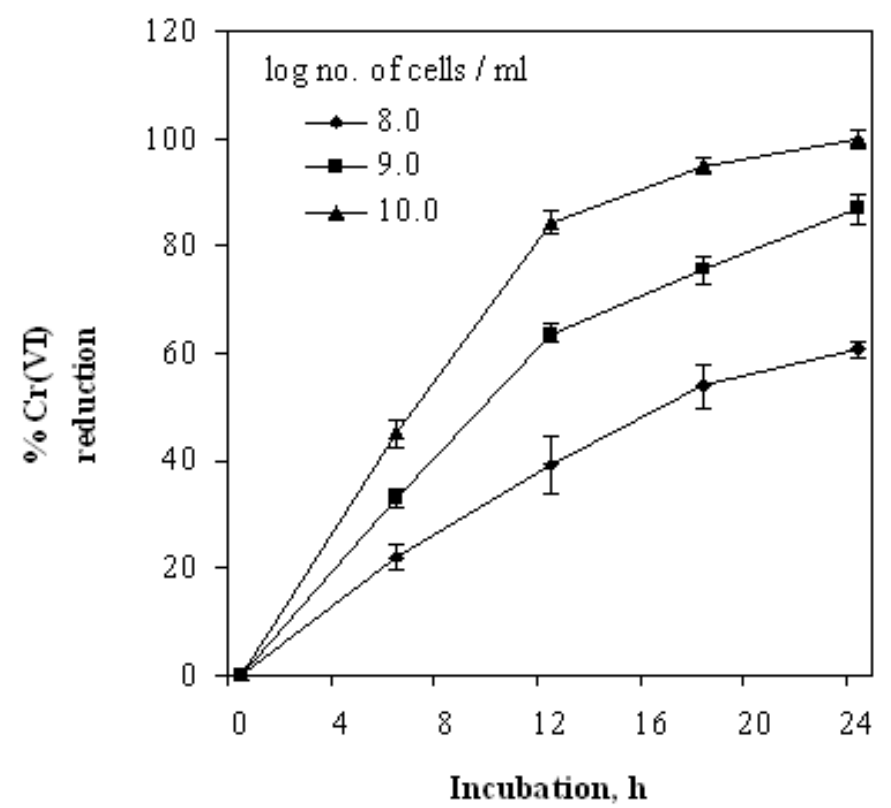

Figure 3 - Effect of cell concentration on chromate reduction by PVA-alginate bound cells of Bacillus sphaericus AND 303.

\section{Effect of electron donor}

The supply of a suitable electron donor, including low-molecular weight carbohydrates, amino acids, fatty acids, NADH, etc. is critical for enhancement of biological reduction of chromate (Wang and Shen 1995). Electron donors such as glucose, lactate, NADH, etc. stimulate bacterial cells by increasing the concentration of hydrogen ions, which prevents the migration and toxicity of chromate ions. Moreover, exogenous electron donors are known to increase the bioavailable hydrogen for microbial use which results in a greater extent of $\mathrm{Cr}(\mathrm{VI})$ reduction (Marsh and
McInernay, 2001). The effect of various electron donors such as glucose, glycerol, NADH, yeast extract, tryptone, glycine, acetate and propionate $(0.1 \% \mathrm{w} / \mathrm{v})$ on $\mathrm{Cr}(\mathrm{VI})$ reduction by PVAimmobilized cells was evaluated at a $\mathrm{Cr}(\mathrm{VI})$ concentration of $20 \mu \mathrm{M}$. Results illustrated in Table 2 showed that amongst the electron donors tested, glycerol was the most efficient one, followed by glucose. Moreover, the rate of $\mathrm{Cr}$ reduction was improved by increasing the concentrations of both glucose as well as glycerol and at $0.5 \%(\mathrm{w} / \mathrm{v})$ level complete reduction was achieved in 24 and $18 \mathrm{~h}$, respectively (Fig. 4).

Table 2 - Effect of electron donor on Cr(VI) reduction by PVA immobilized cells of Bacillus sphaericus AND 303.

\begin{tabular}{lccc}
\hline \multirow{2}{*}{ Electron Donor $(\mathbf{0 . 1 \%})$} & \multicolumn{2}{c}{$\mathrm{Cr}(\mathrm{VI}), \boldsymbol{\mu M}$} & \multirow{2}{*}{ Cr(VI) reduction, \% } \\
\cline { 2 - 3 } Glucose & Initial & Final & $86.5 \pm 7.6$ \\
Glycerol & 20 & $2.7 \pm 0.2$ & $89.0 \pm 6.1$ \\
NADH & 20 & $2.2 \pm 0.1$ & $78.5 \pm 3.6$ \\
Yeast Extract & 20 & $4.3 \pm 0.1$ & $72.0 \pm 1.5$ \\
Tryptone & 20 & $5.6 \pm 0.6$ & $54.0 \pm 1.2$ \\
Glycine & 20 & $9.2 \pm 0.5$ & $46.0 \pm 1.3$ \\
Na-acetate & 20 & $10.8 \pm 1.1$ & $22.5 \pm 0.8$ \\
Na-propionate & 20 & $15.3 \pm 0.8$ & $17.5 \pm 0.7$ \\
\hline
\end{tabular}

Experiment was conducted in minimal salt medium and $\mathrm{Cr}(\mathrm{VI})$ was assayed at $24 \mathrm{~h}$ interval. Results represent mean of triplicate experiments $\pm \mathrm{SE}$. 

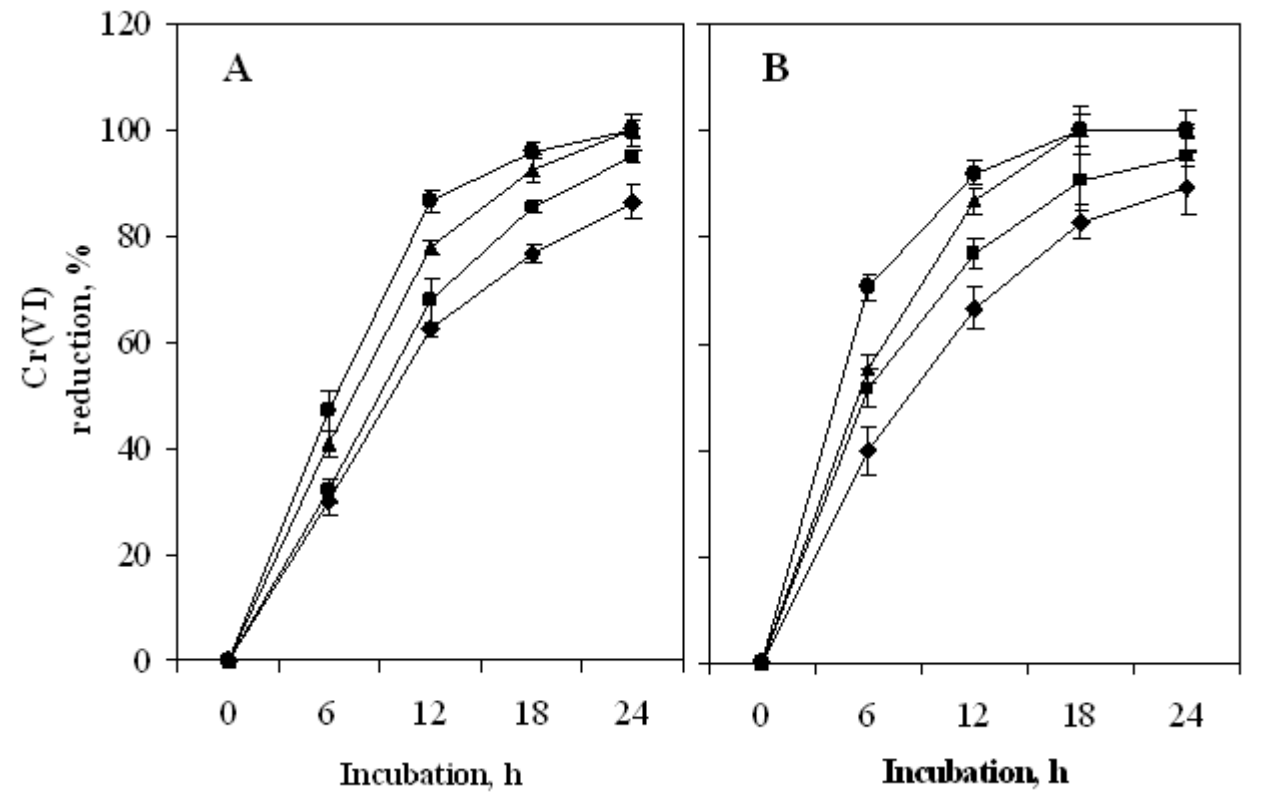

Figure 4 - Effect of glucose (A) and glycerol (B) concentration on $\mathrm{Cr}(\mathrm{VI})$ reduction by PVA-alginate immobilized cells of Bacillus sphaericus AND 303. Reduction experiments were conducted in minimal broth using an initial $\mathrm{Cr}(\mathrm{VI})$ concentration of $20 \mu \mathrm{M}$ supplemented with $0.1 \%\left(--_{-}\right), 0.2 \%(-\mathbf{-}), 0.5 \%\left(-\boldsymbol{\Lambda}_{-}\right)$and $1.0 \%(-\bullet-)(\mathrm{w} / \mathrm{v})$ of glucose and glycerol as electron donors. Residual $\mathrm{Cr}(\mathrm{VI})$ was estimated at $6 \mathrm{~h}$ interval following diphenyl carbazide method.

Significant increase in the rate of $\mathrm{Cr}(\mathrm{VI})$ reduction by the addition of an exogenous electron donor such as glucose or glycerol has been observed in several $\mathrm{Cr}(\mathrm{VI})$ reducing bacteria such as Enterobacter cloacae (Ohtake et al. 1990), Arthrobacter rhombi (Elangovan et al. 2010), Pseudomonas aeruginosa (Ganguli et al. 2002), Bacillus stearothermophilus (Manolov et al. 1995), etc.

\section{Effect of other heavy metals}

The influence of metal ions such as $\mathrm{Ni}(\mathrm{II}), \mathrm{Cd}(\mathrm{II})$, $\mathrm{Co}(\mathrm{II}), \mathrm{Cu}$ (II) (as chloride salts) and $\mathrm{Pb}$ (II) (as nitrate) on the reduction of $\mathrm{Cr}(\mathrm{VI})$ was studied using glucose as electron donor. The presence of each of these metals along with $\mathrm{Cr}(\mathrm{VI})$ at equimolar concentration in the reaction mixture inhibited the chromate reduction process significantly. The degree of inhibition was recorded as follows: $\mathrm{Ni}$ (II) $>\mathrm{Cd}$ (II) $>\mathrm{Pb}$ (II) > $\mathrm{Co}(\mathrm{II})>\mathrm{Cu}(\mathrm{II})$ (Table 3). Copper was least inhibitory and immobilized cells of AND 303 reduced $>60 \%$ of $20 \mu \mathrm{M} \mathrm{Cr}(\mathrm{VI})$ in $24 \mathrm{~h}$. Likewise, $\mathrm{Hg}(\mathrm{II})$ or $\mathrm{Ag}(\mathrm{II})$ strongly inhibited
$\mathrm{Cr}(\mathrm{VI})$ reduction in Escherichia coli ATCC 33456 (Bae et. al. 2000). However, reductase activity in Enterobactor cloacae (Wang et. al. 1990) was completely blocked by $\mathrm{Ag}$ (II) and $\mathrm{Hg}$ (II). Such inhibitory effects could be attributed to the interference of these metal ions with the uptake of $\mathrm{Cr}(\mathrm{VI})$ by the bacterial cell and/or other metabolic functions, which eventually inhibited chromate reductase activity (Ohtake and Silver 1994).

\section{Reuse of beads under optimized condition}

Under the optimized conditions, using an initial 20 $\mu \mathrm{M} \mathrm{Cr}(\mathrm{VI}) ; 0.5 \%$ (w/v) glycerol and a cell concentration of $10^{10}$ cells $/ \mathrm{ml}$, PVA-alginate immobilized cells of B. sphaericus AND 303 could be used up to three cycles with restoration of complete reduction ability in first two cycles (Fig. 5). In the first cycle, the available chromate was completely reduced in $18 \mathrm{~h}$, while the same took $24 \mathrm{~h}$ for reducing the similar amount of chromate in the $2^{\text {nd }}$ cycle. It was interesting to note that under the optimized conditions, a $30 \%$ increase in chromate reduction was recorded in the $3^{\text {rd }}$ cycle as against un-optimized state (Fig. 2). 
Table 3 - Effect of other heavy metals on Cr(VI) reduction by PVA immobilized cells of Bacillus sphaericus AND 303.

\begin{tabular}{|c|c|c|c|c|}
\hline \multirow{2}{*}{ Metals } & \multicolumn{2}{|c|}{$\operatorname{Cr}(V I), \mu M$} & \multirow{2}{*}{$\begin{array}{c}\mathrm{Cr}(\mathrm{VI}) \text { reduction, } \\
\%\end{array}$} & \multirow{2}{*}{ Inhibition, \% } \\
\hline & Initial & Final & & \\
\hline Control (only $\mathrm{Cr}$ ) & 20 & $2.35 \pm 0.3$ & $88.2 \pm 6.5$ & 0 \\
\hline $\mathrm{Cu}(\mathrm{II})+\mathrm{Cr}(\mathrm{VI})$ & 20 & $7.5 \pm 0.1$ & $62.5 \pm 2.5$ & 29.18 \\
\hline $\mathrm{Co}(\mathrm{II})+\mathrm{Cr}(\mathrm{VI})$ & 20 & $9.75 \pm 0.1$ & $51.2 \pm 3.0$ & 41.93 \\
\hline $\mathrm{Pb}(\mathrm{II})+\mathrm{Cr}(\mathrm{VI})$ & 20 & $11.25 \pm 0.5$ & $43.7 \pm 1.5$ & 50.42 \\
\hline $\mathrm{Cd}(\mathrm{II})+\mathrm{Cr}(\mathrm{VI})$ & 20 & $12.8 \pm 1.2$ & $36.0 \pm 4.5$ & 59.21 \\
\hline $\mathrm{Ni}(\mathrm{II})+\mathrm{Cr}(\mathrm{VI})$ & 20 & $14.15 \pm 0.5$ & $29.2 \pm 2.6$ & 66.86 \\
\hline
\end{tabular}

$\mathrm{Cr}(\mathrm{VI})$ reduction in minimal salts broth was assayed after $24 \mathrm{~h}$ interval following diphenylcarbazide method. Heavy metals were added in equimolar concentration as $\mathrm{Cr}(\mathrm{VI})$. Results represent mean of triplicate experiments $\pm \mathrm{SE}$.

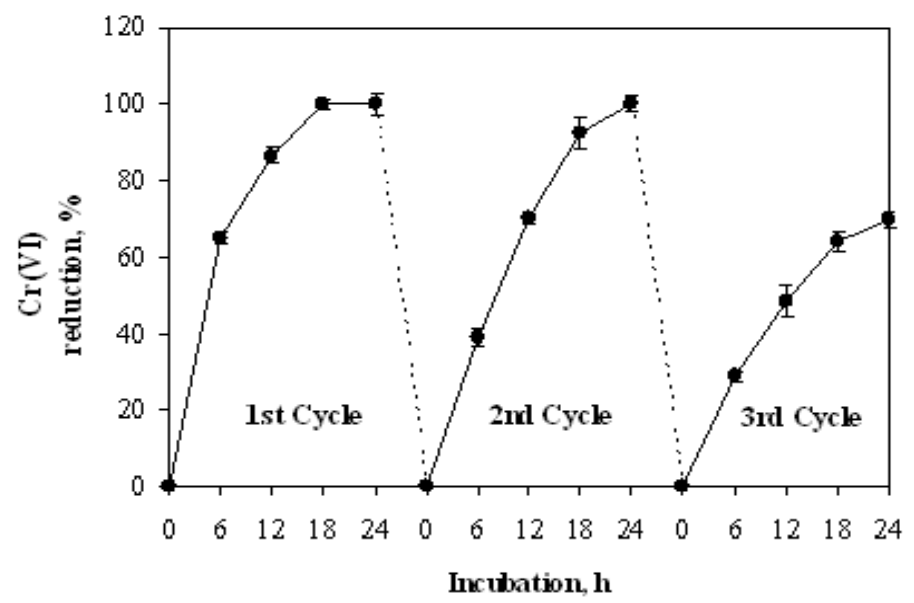

Figure 5 - Reusability of PVA-alginate immobilized cells of Bacillus sphaericus AND 303 in batch operations. Cr(VI) reduction were conducted in shaking condition $(120 \mathrm{rpm})$ for $24 \mathrm{~h}$ cycle at $32^{\circ} \mathrm{C}$. Beads ( $10 \mathrm{mg}$ wet cells per bead) from each cycle were washed with sterile distilled water and transferred to fresh minimal broth supplemented with $20 \mu \mathrm{M} \mathrm{Cr}(\mathrm{VI})$ and $0.5 \%$ glycerol as electron donor.

The gradual decrease in the reduction of $\mathrm{Cr}(\mathrm{VI})$ after $3^{\text {rd }}$ cycle (Fig. 2) could be attributed to the loss of matrix stability as well as release of $B$. sphaericus cells and reductase in the long term shaking incubation and repeated wash as observed in Pseudomonas aeruginosa (Pang et al. 2011), Desulfovibrio vulgaris and Microbacterium sp. (Humphries et al. 2005) The deterioration or changes of biochemical features of the strain during the process of reduction could be another possibility (Pang et al. 2011). The understanding of this phenomenon could be used to improve the stability of B. sphaericus cells in order to apply it in an efficient continuous reduction system.

\section{CONCLUSION}

B. sphaericus AND 303 was successfully entrapped in PVA-alginate beads and exhibited significant chromate reducing activity. Chromate removal was observed in batch experiments without any hindrance towards the accessibility of $\mathrm{Cr}(\mathrm{VI})$ or electron donors to the cells present in the immobilized beads and were able to reduce $20 \mu \mathrm{M}$ $\mathrm{Cr}$ (VI) completely within $18 \mathrm{~h}$ under the optimized condition. The ability of PVA-alginate immobilized cells to be recycled at least three times clearly indicated that B. sphaericus AND 303 could be a promising system for the development of a continuous bioprocess in the treatment of $\mathrm{Cr}(\mathrm{VI})$ contaminated effluents. 


\section{REFERENCES}

Bae WC, Kang TG, Kang IK, Won YJ, Jeong BC. Reduction of hexavalent chromium by Escherichia coli ATCC 33456 in batch and continuous cultures. $J$. Microbiol. 2008; 38: 36-39.

Cervantes C, Campos-Garcia J, Devars S, GutierrezCorona F, Loza-Tavera H, Torres-Guzman JC, Moreno-Sanchez R. Interactions of chromium with microorganisms and plants. FEMS Microbiol. Rev. 2001, 25: 335-347.

Cordoba A, Vargas P, Dussan J. Chromate reduction by Arthrobacter CR47 in biofilm packed bed reactors. $J$. Haz. Mat. 2008; 151: 274-279

Elangovan R, Philip L, Chandraraj K. Hexavalent chromium reduction by free and immobilized cellfree extract of Arthrobacter rhombi - RE. Appl. Biochem. Biotechnol. 2010; 160: 81-97.

Ganguli A, Tripathi AK. Bioremediation of toxic chromium from electroplating effluent by chromatereducing Pseudomonas aeruginosa A2Chr in two bioreactors. Appl. Microbiol. Biotechnol. 2002; 58: 416-420.

Humphries AC, Nott KP, Hall LD, Macaskie LE. Reduction of $\mathrm{Cr}(\mathrm{VI})$ by immobilized cells of Desulfovibrio vulgaris NCIMB 8303 and Microbacterium sp. NCIMB 13776. Biotechnol. Bioeng. 2005; 90: 589-596.

Manolov RJ, Kambourova MS, Emanuilova EI. Immobilization of Bacillus stearothermophilus cells by entrapment in various matrices. Proc. Biochem. 1995, 30: 141-144.

Marsh TL, McInernay MJ. Relationship of hydrogen bioavailability to chromate reduction in aquifer sediments. Appl. Environ. Microbiol. 2001, 67: 15171521.

Nilsson K, Birnbaum S, Flygare S, Linse L, Schroder U, Jepfson U, Larsson PO, Mosbach IC, Brodelius P. A general method for the immobilization of cells with preserved viability. Eur. J. Appl. Microbiol. Biotechnol. 1983, 17: 319-326.

Ohtake H, Komori K, Cervantes C. Chromateresistance in a chromate-reducing strain of Enterobacter cloacae. FEMS Microbiol. Lett. 1990, 67: 85-88.

Ohtake H, Silver S. Bacterial detoxification of toxic chromate. In Choudhuri GR, editor. Biological degradation and bioremediation of toxic chemicals. New York: Springer, 1994; 403-415.

Pal A, Dutta S, Paul AK. Reduction of hexavalent chromium by cell-free extract of Bacillus sphaericus AND 303 isolated from serpentine soil. Curr. Microbiol. 2005; 51: 327-330.
Pal A, Paul AK. Aerobic chromate reduction by chromium-resistant bacteria isolated from serpentine soil. Microbiol. Res. 2004; 159: 347-354.

Pang Y, Zeng GM, Tang L, Zhang Y, Liu YY, Lei XX, $\mathrm{Wu}$ MS, Li Z, Liu C. Cr(VI) reduction by Pseudomonas aeruginosa immobilized in polyvinyl alchohol/sodium alginate matrix containing multiwalled carbon nanotubes. Biores. Technol. 2011, 102: 107733-10736.

Park CH, Keyhan B, Wielinga B, Fendorf S, Matin A. Purification to homogeneity and characterization of a novel Pseudomonas putida chromate reductase. Appl. Environ. Microbiol. 2000, 66: 1788-1795.

Pattanapipitpaisal P, Brown NL, Macaskie LE. Chromate reduction by Microbacterium liquefaciens immobilised in polyvinyl alcohol. Biotechnol. Lett. 2001; 23: 61-65.

Philip L, Iyengar L, Venkobachar C. Immobilized microbial reactor for the biotransformation of hexavalent chromium. Int. J. Environ. Pollut. 1999, 11: 202-210.

Poopal AC, Laxman RS. Hexavalent chromate reduction by immobilized Streptomyces griseus. Biotechnol. Lett. 2008; 30: 1005-1010.

Shen H, Wang YT. Characterization of enzymatic reduction of hexavalent chromium by Escherichia coli ATCC 33456. Appl. Environ. Microbiol. 1993; 59: 3771-3777.

Tucker MD, Barton LL, Thomson BM. Reduction of $\mathrm{Cr}$, Mo, Se and $\mathrm{U}$ by Desulfovibrio desulfuricans immobilised in polyacrylamide gels. J. Ind. Microbiol. Biotechnol. 1998, 20, 13-19.

Wang PC, Mori T, Toda K, Ohtake H. Membrane associated chromate reductase activity from Enterobacter cloacae. J. Bacteriol. 1990, 172: 16701672.

Wang Y. Microbial reduction of chromate. In Lovley DR. (editor) Environmental microbe-metal interactions. Washington, American Society for Microbiology Press. 2000, 225-235

Wang YT, Shen H. Bacterial reduction of hexavalent chromium. J. Ind. Microbiol. Biotechnol. 1995, 14: 159-163.

Wu KA, Wisecarver KD. Cell immobilization using PVA crosslinked with boric acid. Biotechnol. Bioeng. 1992, 39: 447-449.
Received: February 03, 2012; Revised: August 07, 2012; Accepted: May 01, 2013. 